\title{
Clinical, Parasitological and Immunological Aspects of Experimental Infection with Trypanosoma evansi in Dogs
}

\author{
Lúcia Padilha Cury Thomaz de Aquino, Rosangela Zacarias Machado ${ }^{+}$, \\ Antônio Carlos Alessi, Luiz Carlos Marques, Márcio Botelho de Castro, \\ Euclides Braga Malheiros
}

\begin{abstract}
Departamento de Patologia Veterinária, Faculdade de Ciências Agrárias e Veterinárias, Unesp, Jaboticabal, 14870-000, SP, Brasil
\end{abstract}

This research investigated the pattern of antibody response by means of enzyme linked immunosorbent assay (Elisa) and indirect fluorescent antibody test (IFAT) through the course of experimental Trypanosoma evansi infection in dogs. Clinical and parasitological features were also studied. The average prepatent period was 11.2 days and parasitaemia showed an undulating course. Biometrical study of parasites revealed a mean total length of $21.68 \mathrm{~mm}$. The disease was characterized by intermittent fever closely related to the degree of parasitaemia and main clinical signs consisted of pallor of mucous membrane, edema, progressive emaciation and enlargement of palpable lymph nodes. Diagnostic antibody was detected within 12 to 15 days and 15 to 19 days of infection by IFAT and Elisa, respectively. High and persistent antibody levels were detected by both tests and appeared not to correlate with control of parasitaemia

Key words: Trypanosoma evansi - dogs - biometry - Elisa - inmunofluorescent antibody test - clinical features

"Surra", the disease caused by Trypanosoma evansi has been reported in many regions of Brazil, where it is also known as "mal das cadeiras". This trypanosomiasis is endemic in the Pantanal of Mato Grosso where it affects mainly horses and assumes great importance since these animals are largely used in management of cattle breeding, the main economic activity in the region. The parasite is also found in capybaras, coatis and dogs (Stevens et al. 1989, Nunes \& Oshiro 1990, Nunes et al. 1993, Silva et al. 1995a). It is proposed that $T$. evansi outbreaks in pantanal matogrossense are governed by factors such as abundance of vector population and also the presence of wildlife reservoirs and domestic carriers, including dogs (Silva et al. 1995a). A study conducted in the Pantanal of Poconé (State of Mato Grosso, Brazil) detected the prevalence of the parasite in $8.6 \%$ of the examined dogs; due to close contact with horses, the dogs can be assumed as relevant reservoirs hosts in the region (Franke et al. 1994).

\footnotetext{
This study received financial support from Fapesp (94/2413-8).

${ }^{+}$Corresponding author. Fax. :+ 55-16-322.4275. E-mail: zacarias@fcav.unesp.br

Received 12 November 1998

Accepted 19 January 1999
}

Diagnosis of $T$. evansi infection by conventional parasitological techniques is satisfactory in animals with acute or subacute infection, when trypanosomes are present in large numbers in the peripheral blood, but it is often more difficult in chronic or latent infections when parasitaemia may be intermittent or very low. Various serological tests based on the detection of circulating antibodies have been developed for use in the diagnosis of this trypanosomiais, including indirect haemagglutination (Jaktar \& Singh 1971, Verma \& Gautman 1977), complement fixation reaction (Gill 1965), direct agglutination (Monzon 1993, Monzon et al. 1994). Recently, promising results have been obtained with indirect fluorescent antibody test (IFAT) and enzyme-linked immunosorbent assay (Elisa) methods. The IFAT has shown to be sensitive when employed in rabbits (Luckins et al. 1978) and horses (Bakos \& Bustamant 1982, Monzon 1987, Marques 1996) as well as the Elisatest in camels, horses, water buffaloes and cattle (Rae et al. 1989, Payne et al. 1991). The present work investigated clinical and parasitological features and the pattern of humoral immune response along the experimental infection with $T$. evansi in dogs.

\section{MATERIALS AND METHODS}

Trypanosomes - A cryopreserved strain of $T$. evansi originally isolated from a naturally infected dog by Moreira and Machado (1985) was inoculated intravenously in a healthy 8-month-old mon- 
grel dog. Blood with high parasitaemia was used for infection of experimental animals and antigen preparation.

Experimental animals and infection - Eight male and female mongrel dogs about eight months of age were used. The animals were raised in the kennel of the Department of Veterinary Pathology, FCAVJ-Unesp and kept in flyproof individual households. Dogs were fed a commercial ration and water was available ad libitum. Before inclusion in this study the dogs were treated with anthelmintics and immunized against infeccious diseases. Four dogs were each innoculated intravenously with $2.2 \times 10^{5}$ trypanosomes (T1, T2, T3 and T4) and four were used as uninfected controls $(\mathrm{C} 1, \mathrm{C} 2, \mathrm{C} 3$ and $\mathrm{C} 4)$.

Collection of blood samples - Five millilitres of blood were collected daily from the infected dogs by venipuncture of peripheral ear vein and used for parasitaemia determination. For serology, approximately $5 \mathrm{ml}$ samples of blood were collected from the jugular vein of infected dogs on days $5,9,12$, $15,19,26,33,40,47,54,61,68,75$ and 82 after infection, and sera were stored at $-20^{\circ} \mathrm{C}$ until use.

Clinical evaluation and parasitaemia estimation - All animals were clinically examined daily. Rectal body temperature was monitored between 8 and $9 \mathrm{hr}$ and every clinical alteration was recorded. Parasitaemia was estimated daily by the count of trypanosomes in a hundred microscopical fields of wet blood film under a 22 x 22 coverslip using a X10 eyepiece and X40 objective. The results were expressed as parasites $/ \mathrm{ml}$, according to methodology described by Brener (1961).

Biometrical study - Measurements of trypanosomes were made in Giemsa stained blood smears in a total of 200 observations ( 50 observations/infected animal) using an video-image analysis system (Videoplan, Kontron Elektronic, Carl Zeiss do Brasil).

Antigen preparation - Pure trypanosomes were isolated from infected blood by anion-exchange chromatography on a column of diethylaminoethyl (DEAE) cellulose, as described by Lanham and Godfrey (1970) with minor modifications. The separated trypanosomes were washed three times by centrifugation with $0.1 \mathrm{M}$ phosphate - buffered saline (PBS) pH 7.4 and resuspended in saline solution $0.85 \%$.

For use in IFAT the suspension containig pure trypanosomes was distributed in slides inside delimited cavities previously prepared with nail polish. The slides were air-dried, individually wrapped in tissue paper and stored at $-20^{\circ} \mathrm{C}$. Trypanosomes were dysrupted by three cycles of freezing $\left(-20^{\circ} \mathrm{C}\right)$ followed by thawing at room temperature for preparation of soluble antigen used in Elisa-test. Solid debris was removed by centrifugation at $10,000 \mathrm{~g}$ for $20 \mathrm{~min}$ at $4^{\circ} \mathrm{C}$ and the supernatefluid collected for soluble antigen content. Protein content was determined as described by Hartree (1972), using bovine serum albumin (Bio-Rad Laboratories) as standard. Antigen was subsequently stored at $-20^{\circ} \mathrm{C}$ until use.

Elisa procedure - The technique used was essentially that described by Machado et al. (1997). Plates were coated with $10 \mathrm{mg} / \mathrm{ml}$ of the soluble antigen, the test and control sera were diluted 1:200 and the conjugate, rabbit anti-dog IgG conjugated to alkaline phosphatase (Sigma A6042), was diluted 1:9000. All test and control sera were tested in duplicate. The mean absorbance of tested sera were grouped into Elisa levels (EL), which range from 0 to 9 . The maximal limit of level 0 was determined by the mean absorbance of negative control sera $(n=10)$ with addition of twice the standard deviation. The subsequent levels were determined by increment of $35 \%$, as described by Machado et al. (1997) for the Babesia system.

IFAT - For use in the test the slides were brought to room temperature and successive serum sample dilutions in PBS (1:40, 1:80, 1:160, etc.) and known positive and negative control sera were placed in the defined areas containig the antigen. The slides were then incubated in a humid chamber at $37^{\circ} \mathrm{C}$ for $45 \mathrm{~min}$ and washed three times $(5 \mathrm{~min}$ each wash) in PBS. After drying, the slides were incubated with a 1:20 dilution of rabbit anti-dog IgG fluorescein conjugate (Sigma F4012) for $45 \mathrm{~min}$ at $37^{\circ} \mathrm{C}$. After washing, as previously described, the slides were air-dried and mounted with $9 / 1$, $\mathrm{v} / \mathrm{v}$, glycerol/sodium bicarbonate $\mathrm{pH} 9.5$ and examined using an ultraviolet microscope (Carl Zeiss, mod. ST 44).

Statistical analysis - Pearson's correlation coefficient was employed to evaluate the effect of parasitaemia over temperature. The two serological tests were compared using the Chi-square test.

\section{RESULTS}

Parasitaemia and biometrical data - Parasites were detected in the blood of infected dogs within 9 and 17 days after inoculation, with mean prepatent period of 11.2 days. Thereafter the parasitaemia showed the same pattern in all infected dogs, displaying relapsing and undulating course. The first peak of parasitaemia occured 3 days after the appearance of the trypanosomes and parasitaemia levels fluctuated with a frequency of about 3 to 7 days between peaks; aparasitaemic periods ranging from 1 to 3 days were observed after 60 days of infection.

The results of measurements of $T$. evansi from infected dogs are shown in the Table. 
TABLE

Measurements data of Trypanosoma evansi from experimentally infected dogs $(n=200)$

\begin{tabular}{lrrrc}
\hline $\begin{array}{l}\text { Measure } \\
(\mathrm{mm})\end{array}$ & Minimal & Maximum & Mean & $\begin{array}{c}\text { Standard } \\
\text { error }\end{array}$ \\
\hline $\mathrm{T}$ & 16.01 & 27.06 & 21.68 & \pm 1.88 \\
$\mathrm{~F}$ & 2.48 & 9.86 & 6.65 & \pm 1.27 \\
$\mathrm{PN}$ & 5.19 & 10.71 & 7.98 & \pm 0.99 \\
$\mathrm{NA}$ & 4.53 & 11.11 & 7.11 & \pm 1.28 \\
\hline
\end{tabular}

$\mathrm{T}$ : total lenght, F: lenght of free flagellum, PN: distance from posterior end to middle of nucleus, NA: distance from nucleus to anterior end.

Clinical findings - The main clinical signs observed in infected dogs were fever, pale mucous membranes, progressive emaciation and enlargement of palpable lymph nodes. Mean rectal temperatures were statistically higher $(\mathrm{p}<0.01)$ in infected dogs than in non infected animals and went up to $40-41{ }^{\circ} \mathrm{C}$. Body temperature of all infected animals increased soon after infection and thereafter oscillated a great deal, usually in concern with the waves of parasitaemia (Fig. 1). A positive correlation ( $p<0.01)$ was statistically detected between the intensity of parasitaemia and the mean temperatures of infected dogs.

Elisa-test - The mean absorbance for the negative control sera $(n=10)$ was $0.113 \pm 0.013$. Then, EL were defined as follows:

$\begin{array}{lc}\text { EL } & \text { Absorbance } \\ 0 & 0.000-0.139 \\ 1 & 0.140-0.187 \\ 2 & 0.188-0.253 \\ 3 & 0.254-0.341 \\ 4 & 0.342-0.461 \\ 5 & 0.462-0.623 \\ 6 & 0.624-0.841 \\ 7 & 0.842-1.136 \\ 8 & 0.137-1.533 \\ 9 & 31.534\end{array}$

The results of Elisa-test (expressed as EL) employed in sera from infected dogs are illustrated in Fig. 2.

Antibodies of diagnostic value (EL 33 ) were detected within 15 days after infection in animal $\mathrm{T} 1$ and $\mathrm{T} 2$, when maximal titres $(\mathrm{EL}=7)$ were reached. Following a sharp decline, antibody values increased gradually and returned to EL 7 at 47 days p.i. in animal $\mathrm{T} 1$ and at 33 days p.i. in dog T2. Both sera remained at this plateau level until the end of the experimental period.

Dogs T3 and T4 became Elisa positive within 19 days after infection and values increased pro-
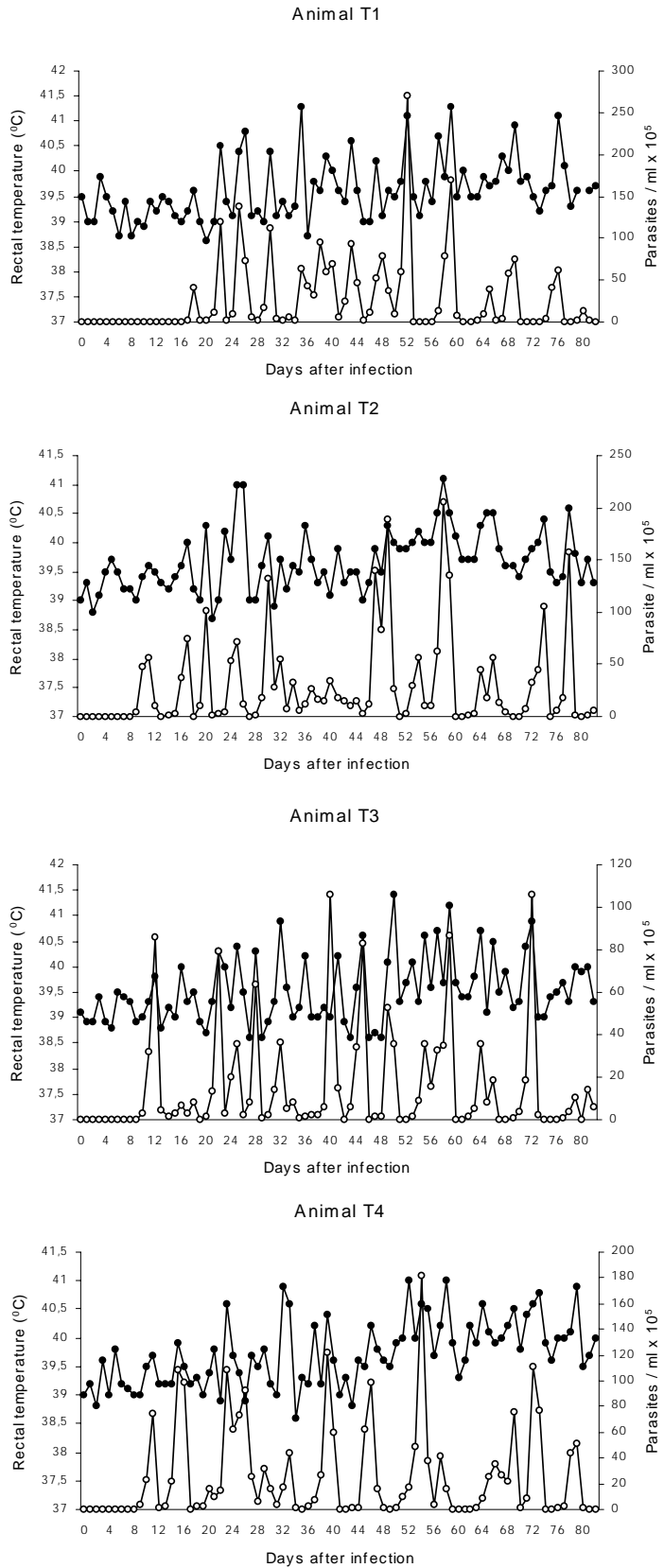

Fig. 1: rectal body temperature (- - ) and parasitaemia (—- - of infected dogs along the experimental period.

gressively to maximum levels (EL 7) by 40 days of infection. Animal T3 and T4 showed little or no decline in antibody levels until the end of the study. Uninfected control animals remained negative throughout the study.

IFAT - Final dilutions of sera from infected dogs expressed as their correspondent log values are illustrated in Fig. 2. 

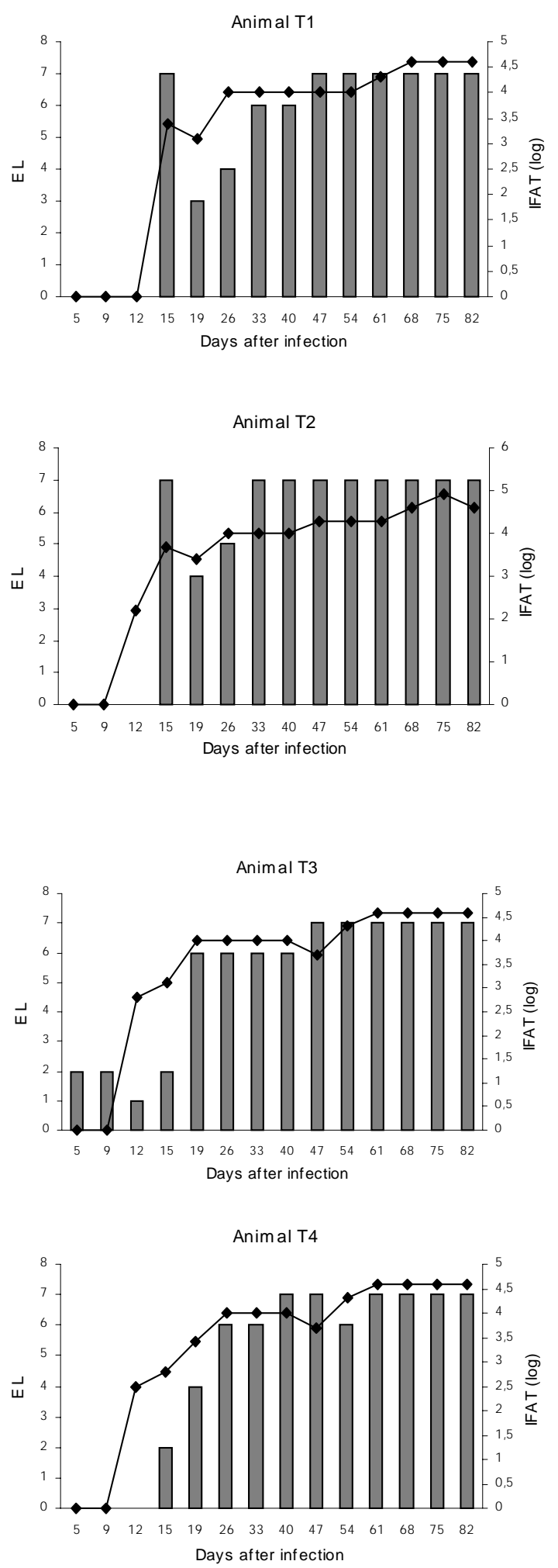

Fig. 2: kinectic of humoral immune response of experimentally infected dogs by means of Elisa-test $(\square)$ and IFAT $(-\bullet-)$ along the experimental period.
IFAT revealed an homogeneous humoral response pattern in all infected animals. Antibodies of diagnostic value were first detected 12 days after infection in animals T2, T3 and T4 and by 15 days in animal T1. Thereafter, apart from a slight decrease observed in dogs T1 and T2, antibody titres increased progressively. Maximun positive dilutions (1:40960) were reached within 61 days in animals $\mathrm{T} 3$ and $\mathrm{T} 4$ and by 68 days in animals $\mathrm{T} 1$ and T2. Titres persisted until the end of the experiment with the exception of dog T2 which reached a positive dilution of 1:81920 at day 75 p.i. Antibodies were not detected in sera from uninfected control animals.

\section{DISCUSSION}

The mean prepatent period (11.2 days) observed in infected dogs was longer than those found in experimental infection in horses (Monzon et al. 1984, Oshiro et al. 1989) and dogs (Galhorta et al. 1986, Ravi \& Sapre 1994). The undulating course of parasitaemia and the high peaks observed throughout all the experimental period may be related to the phenomenon of antigenic variation. It has been shown that $T$. evansi undergoes antigenic variation during the course of infection in a number of vertebrate host species (Jones \& McKinnell 1985). In our experiment the course of parasitaemia was usually synchronized with that of fever. This positive corrrelation between parasitaemia and body temperature, is in accordance with previous investigations on experimental infection in dogs (Ravi \& Sapre 1994) and horses (Oshiro et al. 1989).

All clinical signs observed in infected dogs are similar to those already reported in naturally infected dogs (Hellebrekers \& Slappendell 1982, Moreira \& Machado 1985, Ravi \& Saprei 1994, Silva et al. 1995b). Other frequently reported clinical signs such as keratitis, hemorrhageae in the anterior eye chamber and motorial disturbance (May 1968, Hellebrekers \& Slappendel 1982) could not be observed in our experimental animals. Appetite remained unaltered during the experimental period, and is clearly unrelated to emaciation observed in infected animals. The febrile response of infected dogs may have contributed to weight loss. Furthermore, the complex immunological and physiological changes caused by the parasite result in reduced catabolic activity (Seed \& Hall 1985).

The serological tests employed in infected dogs sera showed suitable for identifying $T$. evansi infection, since they detected $100 \%$ of positive sera. Trypanosomal antibodies were first detected by IFAT within 12 and 15 days p.i. and betwwen 15 and 19 days p.i. by Elisa-test. These findings are 
similar to those described by other workers using both tests in sera of rabbits (Luckins et al. 1978) and camels (Luckins et al. 1979) where antibodies were revealed within 10 to 15 days after infection. Even though IFAT was precocious in detecting trypanosomal antibodies, the pattern of antibody production measured by Elisa and IFAT was very similar revealing a good agreement between both tests. High antibody titres were obtained by both tests and remained until the end of the study. Changes in antibody profile of an infected host can be used as an indicator of the humoral immune system which is considered to be an essential component of the defence mechanism against trypanosomes (Morrison et al. 1985). In the present study, however, antibody levels did not appear to correlate with ability to control parasitaemia, since high levels of parasitaemia persisted througout the studied period parallel to high antibody titres.

\section{ACKNOWLEDGEMENTS}

To Isabel Aparecida Valli, Marcos Tadeu Christóforo and Rosângela Y Andrade for technical assistance. To Ronaldo Del Vechio for the care of animals.

\section{REFERENCES}

Bakos E, Bustamante A 1982. Detection de titulos serológicos anti-Trypanosoma equinum em sueros de equinos (segunda parte - comparando los titulos serológicos con la parasitemia). Gac Vet B Aires 44: 305-309.

Brener Z 1961. Contribuição ao Estudo da Terapêutica Experimental da Doença de Chagas, Thesis, Faculdade de Odontologia e Farmácia, Universidade Federal de Minas Gerais, Belo Horizonte.

Franke CR, Greiner M, Mehlitz D 1994. Investigation on naturally ocurring $T$. evansi infections in horses, cattle, dogs and capybaras (Hydrochaeris hydrochaeris) in Pantanal de Poconé (Mato Grosso, Brazil). Acta Trop 58: 159-169.

Galhorta AP, Singh MP, Gautman OP 1986. Biochemical changes and therapeutic trials in experimental trypanosomiasis in dogs. Indian J Parasitol 10: 253257.

Gill BS 1965. Studies on serological diagnosis of Trypanosoma evansi. J Comp Pathol 75: 175-183.

Hartree EF 1972. Determination of protein: A modification of the Lowry method that gives a linear photometric response. Anal Biochem 48: 422-427.

Hellebrekers LJ, Slappendel RJ 1982. Tripanosomiasis in a dog imported in the Netherlands. Vet $Q 4$ : 182 186.

Jaktar PR, Singh M 1971. Diagnosis of Surra in camels by the passive haemagglutination test. Br Vet J 127: 283-288.

Jones TW, Mckinnell CD 1985. Antigenic variation in Trypanosoma evansi: variable antigen type development in mice, sheep and goats. Trop Med Parasitol 36: $53-57$

Lanhan SM, Godfrey DG 1970. Isolation of salivarian tripanosomes from man and other mammals using DEAE cellulose. Exp Parasitol 28: 521-534.

Luckins AG, Gray AR, Rae P 1978. Comparison of the diagnostic value of serum immunoglobulin levels, an enzime-linked immunosorbent assay and a fluorescent antibody test in experimental infections with Trypanosoma evansi in rabbits. Ann Trop Med Parasitol 72: 429-441.

Luckins AG, Boid R, Era P, Mahmoud MM, Malik EL, Gray AR 1979. Serogiagnosis of infection with Trypanosoma evansi in camels in the Sudan. Trop Anim Health Prod 11: 1-12.

Machado RZ, Montassier HJ, Pinto AA, Lemos, EG, Machado MRF, Valadão IFF, Barci LG, Malheiros EB 1997. An enzyme-linked immunosorbent assay (Elisa) for detection of antibodies against Babesia bovis in cattle. Vet Parasitol 71: 17-26.

Marques LC 1996. Infecção Experimental em Eqüinos com Trypanosoma evansi Steel, 1885 (Sarcomastigophora: Trypanosomatidae), Thesis, Faculdade de Ciências Agrárias e Veterinárias, Universidade Estadual Paulista, Jaboticabal, 134 pp.

May C 1968. Canine meningo-encephalitis due to Trypanosoma evansi infection (A report of two cases). Vet Rec 83: 663-665.

Monzon CM 1987. Inmunodiagnóstico de la tripanosomiasis equina o mal de caderas, mediante la prueba de inmunofluorescencia indirecta. Rev Med Vet (Bs As) 68: 196-204.

Monzon CM 1993. Serological diagnosis of Trypanosoma evansi (Steel 1885) in horses using a direct agglutination test. Vet Parasitol 47: 25-35.

Monzon CM, Jara GA, Hoyos CB 1994. Evaluacion de la prueba de aglutinacion directa en el diagnostico del Mal de Caderas en equinos. Rev Inst Med Trop São Paulo 36: 211-215.

Monzon CM, Mancebo OA, Dágostinho BI 1984. Consideraciones clínicas de la tripanosomiasis equina experimental (Trypanosoma equinum, Vóges 1901). Rev Med Vet (Bs As) 65: 13-8.

Moreira RD, Machado RZ 1985. Identificação e isolamento do Trypanosoma equinum em um cão do município de Camapuã-MS, p. 66. Proceedings of $10^{\circ}$ Encontro de Pesquisas Veterinárias, Jaboticabal, SP.

Morrison WI, Murray M, Akol GWO 1985. Immune response of cattle to African trypanosomes, p.103131. In I Tizard, Immunology and Pathogenesis of Tripanosomiasis, CRC Press, Boca Raton, Fl.

Nunes VLB, Oshiro ET 1990. Trypanosoma evansi in the coati from the Pantanal region of Mato Grosso do Sul State, Brazil. Trans R Soc Trop Med Hyg 84: 692.

Nunes VLB, Oshiro ET, Dorval MEC, Garcia LAM, Silva AAP, Bogliolo AR 1993. Investigação epidemiológica sobre Trypanosoma (Trypanozoon) evansi no pantanal sul-mato-grossense. Estudo de reservatórios. Rev Bras Parasitol 2: 41-44.

Oshiro ET, Rodrigues M, Nunes VLB, Ribeiro OC 1989. Trypanosoma (Trypanozoon) evansi (Steel,1885) Balbiani, 1888, infecção experimental em equinos com amostra isolada de capivara, Hydrochaeris hydrochaeris (Linnaeus, 1766) (Rodentia: 
hydrochaeridae). Semina 10: 51-55.

Payne RC, Sukanto IP, Djauhari D, Partoutomo D, Wilson S, Jones AJ, Boid R, Luckins AG 1991. Trypanosoma evansi infection in cattle, buffaloes and horses in Indonesia. Vet Parasitol 38: 109-119.

Rae PF, Thrusfield MV, Higgins A, Aitken CGG, Jones TW, Luckins AG 1989. Evaluation of enzyme immunoassays in the diagnosis of camel (Camelus dromedarius) trypanosomiasis: a preliminary investigation. Epidem Inf 102: 297-307.

Ravi P, Sapre VA 1994. Effect of dexamethasone on the course of experimental Trypanosoma evansi infection in dogs. Indian Vet $J$ 71: 403-404.

Seed JR, Hall JE 1985. Pathophisiology of African trypanosomiasis, p. 1-11. In I Tizard, Immunology and Pathogenesis of Trypanosomiasis, CRC Press, Boca Raton, Fl.

Silva RAMS, Barros ATM, Herrera HM 1995a.
Trypanosomosis outbreaks due to Trypanosoma evansi in the Pantanal, Brazil. A preliminary approach on risk factors. Révue Élev Méd Vét Pays Trop 48: 315-319.

Silva RAMS, Herrera HM, Domingos LBS, Ximenes FA, Dávila AMR 1995b. Pathogenesis of Trypanosoma evansi infection in dogs and horses: haematological and clinical aspects. Ciênc Rur 25: 223-238.

Stevens JR, Nunes VLB, Lanham SM, Oshiro ET 1989. Isoenzyme characterization of Trypanosoma evansi isolated from capybaras and dogs in Brazil. Acta Trop 46: 213-222.

Verma BB, Gautman OP 1977. Serological diagnosis of experimental bovine surra (Trypanosoma evansi infection) - A comparison of passive haemagglutination, gel diffusion and indirect fluorescent antibody tests. Indian Vet J 54: 809-813. 